\title{
Oil Price Volatility and U.S. Macroeconomic Activity
}

\author{
Hui Guo and Kevin L. Kliesen
}

\begin{abstract}
Oil shocks exert influence on macroeconomic activity through various channels, many of which imply a symmetric effect. However, the effect can also be asymmetric. In particular, sharp oil price changes-either increases or decreases-may reduce aggregate output temporarily because they delay business investment by raising uncertainty or induce costly sectoral resource reallocation. Consistent with these asymmetric-effect hypotheses, the authors find that a volatility measure constructed using daily crude oil futures prices has a negative and significant effect on future gross domestic product (GDP) growth over the period 1984-2004. Moreover, the effect becomes more significant after oil price changes are also included in the regression to control for the symmetric effect. The evidence here provides economic rationales for Hamilton's (2003) nonlinear oil shock measure: It captures overall effects, both symmetric and asymmetric, of oil price shocks on output.
\end{abstract}

Federal Reserve Bank of St. Louis Review, November/December 2005, 87(6), pp. 669-83.

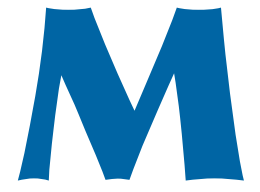

onetary policymakers are concerned with large price movements in the crude oil market, and Figure 1 explains why. ${ }^{1}$ It shows that most U.S. post-World War II recessions, including the most recent 2001 recession, were preceded by sharp increases in crude oil prices. One conventional explanation is that oil price increases lower future GDP growth by raising production costs. Alternatively and complementarily, large oil price changes-either increases or decreases-may affect aggregate output adversely because they delay business investment by raising uncertainty or they induce costly sectoral resource reallocation.

In this paper, we explicitly distinguish between these two channels through which changes in oil prices affect aggregate economic

1 Unless otherwise indicated in our empirical analysis, we use an updated version of Hamilton's (2003) data of both raw and transformed oil prices. We thank James Hamilton for providing the data. activity: (i) the change in the dollar price of crude oil (relative price change) and (ii) the increase in uncertainty about future prices (volatility). It should be noted that, as we discuss in the next section, although the former channel implies a symmetric effect of oil shocks, the latter implies an asymmetric effect. Therefore, a joint consideration of both channels sheds light on Hamilton's (2003) nonlinear oil shock measure: It captures overall effects, both symmetric and asymmetric, of oil price shocks.

We constructed an oil price volatility measure using daily prices of crude oil futures traded on the New York Mercantile Exchange (NYMEX) over the period 1984-2004. Our main results can be summarized as follows. First, as hypothesized, oil price volatility has a negative and significant effect on future GDP growth. Second, this volatility effect becomes more significant after we control for the oil price change, indicating that both channels are potentially important. Third, both the oil price change and its volatility lose their

Hui Guo is a senior economist and Kevin L. Kliesen is an economist at the Federal Reserve Bank of St. Louis. The authors thank James Hamilton for comments and data. Jason Higbee provided research assistance.

(C) 2005, The Federal Reserve Bank of St. Louis. Articles may be reprinted, reproduced, published, distributed, displayed, and transmitted in their entirety if copyright notice, author name(s), and full citation are included. Abstracts, synopses, and other derivative works may be made only with prior written permission of the Federal Reserve Bank of St. Louis. 
significance after we control for Hamilton's (2003) nonlinear oil shock measure. This result confirms that Hamilton's measure captures the overall effects of oil shocks on aggregate output and, therefore, cannot be entirely attributed to data mining, as suggested by Hooker (1996a,b).

It is also important to note that, consistent with work by Hamilton (1983 and 1985) and others, a vast majority of the largest daily oil futures price changes in our data are associated with exogenous events such as wars or political instability in the Middle East. Moreover, the dynamic of the oil price volatility measure cannot be explained by standard macroeconomic variables. This evidence is consistent with a causal interpretation of the macroeconomic effect of oil shocks. ${ }^{2}$

As a robustness check, we measured volatility also using squared quarterly oil price changes over a longer sample, 1947-2004, and obtained very similar results. For example, oil price volatility has a negative and (marginally) significant effect on future GDP growth when combined with oil price changes, which are statistically significant as well. Again, both variables lose their predictive power after we control for Hamilton's (2003) nonlinear oil shock measure.

The remainder of the paper is organized as follows. After providing a brief summary of the relation between oil prices and output, we discuss our measure of realized variance of oil futures prices. We then investigate the relation between realized variance of oil futures prices and various measures of macroeconomic activity.

\section{RELATED LITERATURE}

Hamilton (1983), among many others, has documented a negative and significant relation between oil price changes and future GDP growth. This result, however, breaks down in data after 1986 (e.g., Hooker, 1996a). The unstable relation possibly reflects that Hamilton has implicitly assumed a symmetric effect of oil shocks in his linear specification: An increase (decrease) in oil

2 Barsky and Kilian (2004), however, have argued that causality runs from macroeconomic variables to oil prices. prices reduces (increases) future GDP growth. This specification is consistent with some transmission channels (e.g., Rasche and Tatom, 1977a,b; Baily, 1981; and Wei, 2003) through which oil shocks exert influence on macroeconomic activity. ${ }^{3}$ However, the effect can be also asymmetric: An oil price decrease may actually lower future GDP growth through other channels. In particular, as we investigate in this paper, a sharp oil price change-either increase or decrease-affects the macroeconomy adversely for at least two reasons. First, it raises uncertainty about future oil prices and thus causes delays in business investment (e.g., Bernanke, 1983, and Pindyck, 1991). Second, it induces resource reallocation, for example, from more adversely influenced sectors to less adversely influenced sectors, and such reallocation is costly (e.g., Lilien, 1982, and Hamilton, 1988). Overall, whereas an oil price increase has a negative effect on future GDP growth, the effect of an oil price decrease is ambiguous. That is, given that both the oil price change and volatility are related to future GDP growth, Hamilton's (1983) specification suffers from an omitted variables problem.

As shown in Figure 1, this explanation of the omitted variables problem is plausible. Most oil price changes are positive before 1986; in contrast, oil prices exhibit larger swings in both directions afterward. As a result, although Hamilton's (1983) linear specification is a good approximation before 1986, it is not after 1986 because of the increased importance of nonlinearity induced by large negative oil price changes.

To take into account the asymmetric effect, Hamilton (1996 and 2003) proposed a transformation of raw oil prices. In particular, an oil shock is equal to the difference between the current oil price and the maximum price in the past 4 or 12 quarters if the difference is positive and is equal to zero otherwise. Hamilton found that the transformed oil shock measure exhibits a negative and stable relation with future GDP growth. Figure 2 illustrates his results by showing that a positive oil shock measured using a 12-quarter

\footnotetext{
3 Also see Jones, Leiby, and Paik (2004) for discussion on various transmission channels of oil price shocks.
} 


\section{Figure 1}

\section{Percentage Change in Quarterly Crude Oil Prices}

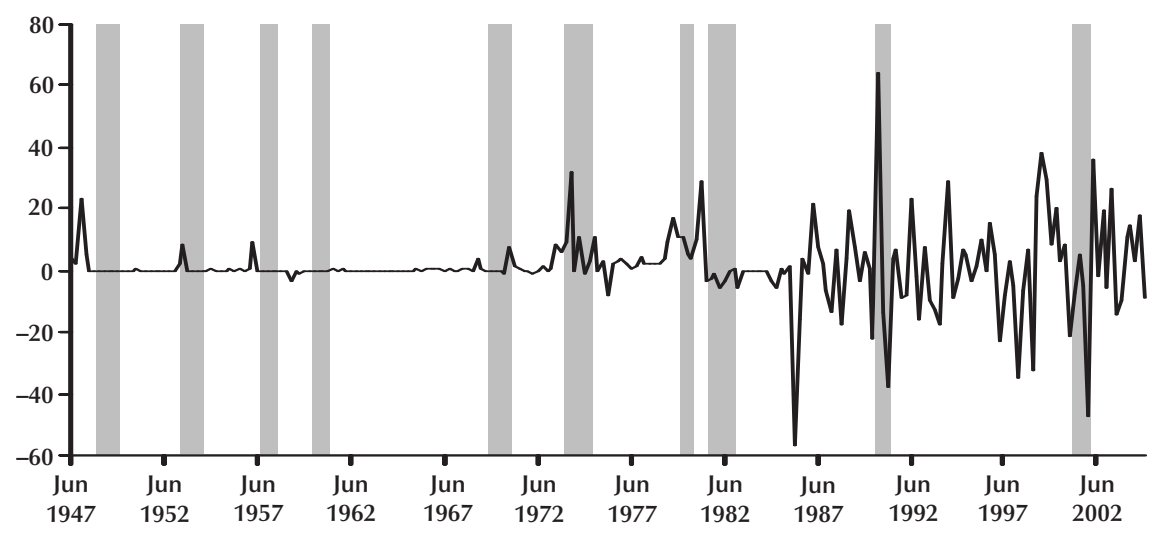

NOTE: Shaded bars indicate National Bureau of Economic Research-dated recessions.

\section{Figure 2}

\section{Hamilton's Oil Shocks Measured Using a 12-Quarter Horizon}

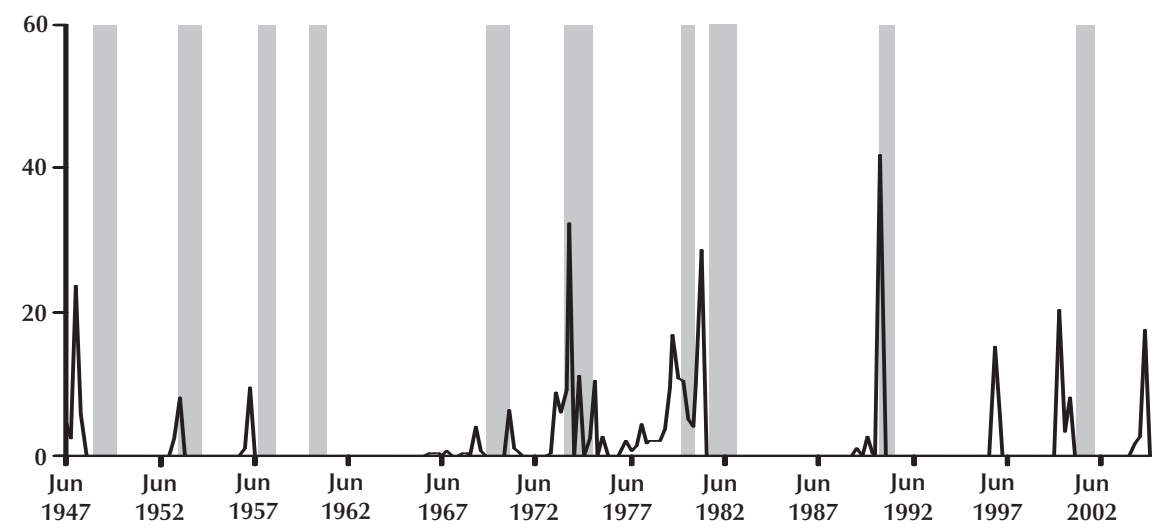

horizon proceeds almost all the recessions in the post-World War II sample. Nevertheless, it is important to verify that Hamilton's measure of oil shocks indeed captures the nonlinear relation between oil prices and real GDP growth; otherwise, it is vulnerable to the criticism of data mining (Hooker, 1996b). That is, if the change and volatility of crude oil prices have distinct effects on the macroeconomy, these effects should be related to or even subsumed by Hamilton's modified oil shock measure. This is the main focus of our paper.

\section{REALIZED OIL PRICE VARIANCE}

We measured uncertainty about oil prices using a realized oil price variance series constructed from daily crude oil futures prices obtained from the NYMEX. In particular, as in Merton (1980) and 
Figure 3

\section{Daily 1-Month and 12-Month Crude Oil Prices}

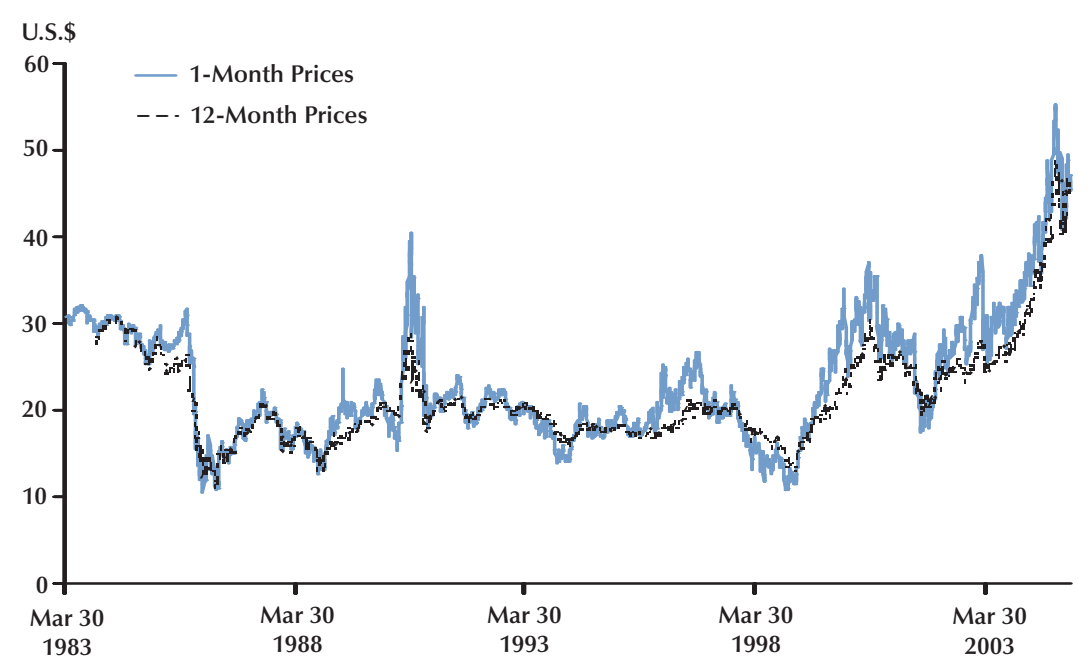

Andersen et al. (2003), among others, quarterly realized oil price variance, $R V_{-} O$, is the sum of squared daily price changes in a quarter:

$$
R V{ }_{-} O_{t}=\sum_{d=1}^{D_{t}}\left(R E T{ }_{-} O_{d}\right)^{2},
$$

where $R E T \_O_{d}$ is the change in daily futures prices in day $d$ of quarter $t .^{4}$ Realized variance of other frequencies (e.g., a month) is defined in a similar manner.

Figure 3 plots daily prices of 1-month (solid line) and 12-month (dashed line) futures contracts of West Texas Intermediate traded on the NYMEX. The data span from April 1983 to December 2004 for the 1-month futures contracts and from December 1983 to December 2004 for the 12month futures contracts. ${ }^{5}$ As seen in the figure, although the two series move similarly, the 1month futures contracts appear to be considerably

4 The volatility measure defined in equation (1) seems to be plausible because changes in daily crude oil futures prices have a sample average close to zero and negligible serial correlation. We found very similar results using various alternative specifications-for example, using the average daily return in a quarter as a proxy for the conditional return or controlling for serial correlation.

5 The 12-month contract is the contract with the most distant maturity and for which daily prices are reliably available since 1984 . more volatile than the 12-month futures contracts. Figure 4 plots realized variance of 1-month (solid line) and 12-month (dashed line) futures contracts from 1984 to 2004 (quarterly). Increased volatility in the prices of 1-month futures contracts probably reflects that the market is more vulnerable to temporary disruptions in supply stemming from strikes, refinery shut-downs, or unexpected changes in inventories. These high-frequency shocks mainly reflect transitory noises, which are unlikely to have any significant effect on investors' perceptions about the uncertainty of future oil prices. Therefore, we focused on the volatility measure using 12-month futures contracts in our empirical analysis; nevertheless, we found qualitatively the same results using futures contracts of different maturities.

Figure 4 also shows that oil price volatility increased dramatically in 1986 and 1990, with the former episode reflecting a steep decline in oil prices and the latter a sharp increase because of the first Gulf War (see Figure 1). However, volatility stays at a relatively low level after the first Gulf War, although oil prices continue to exhibit large swings (see Figure 1). We did not observe any large spikes in realized volatility after 1990, even during the second Gulf War in 


\section{Figure 4}

\section{Realized Oil Price Volatilities: 1-Month and 12-Month Futures Contracts}

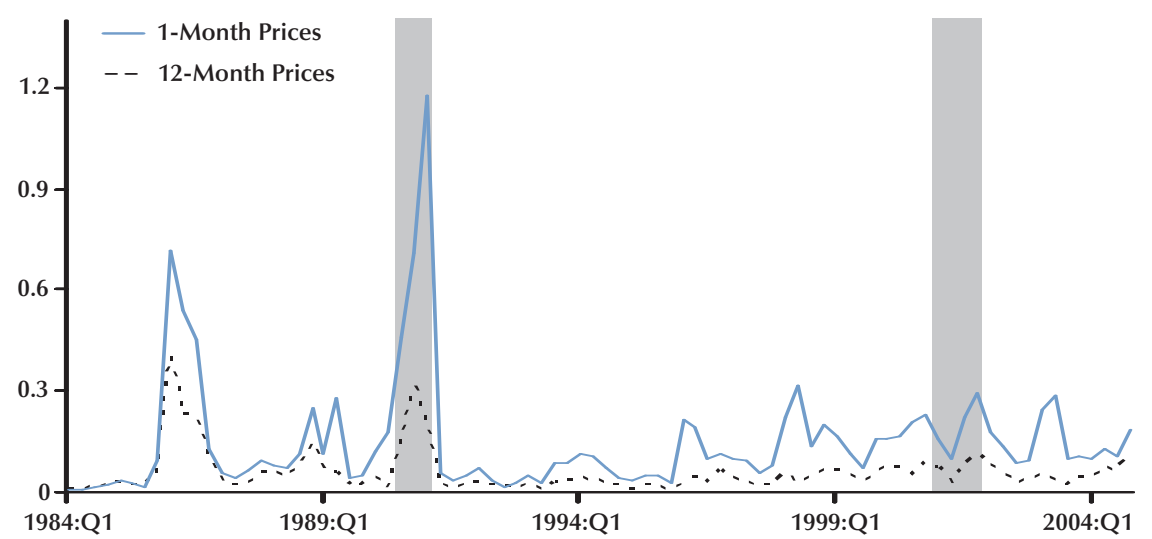

\section{Figure 5}

\section{Quarterly Realized Oil Price Variance and Stock Market Variance}

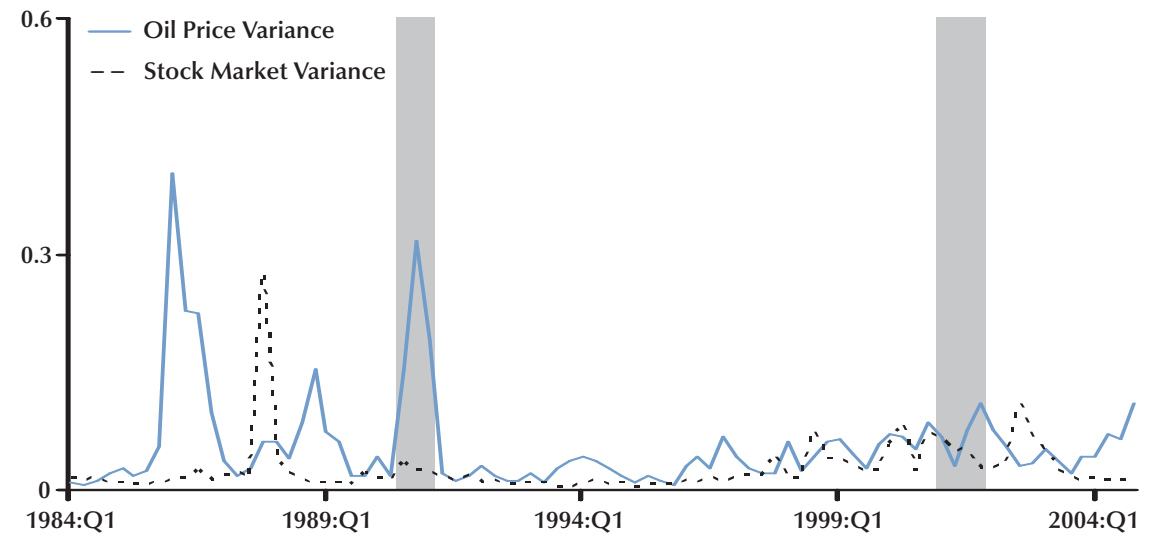

2003 and its aftermath. Moreover, oil price volatility seems to have an upward linear trend after 1990, but we were unable to make any formal inference because of the small number of observations.

Many authors (e.g., Guo, 2002) have shown that stock market volatility also has an adverse effects on aggregate output. Given that stock market prices are equal to discounted future cash flows, oil price volatility might be closely related to stock market volatility. To investigate whether these two volatility measures have similar forecasting power for GDP growth, we also constructed quarterly realized stock market variance, $R V \_S$, using daily stock return data (obtained from Kenneth French at Dartmouth College) ${ }^{6}$ :

$$
R V{ }_{-} S_{t}=\sum_{d=1}^{D_{t}}\left(R E T_{-} S_{d}\right)^{2},
$$

6 We downloaded the data from his homepage: http://mba.tuck.dartmouth.edu/pages/faculty/ken.french. 
where $R E T \_S_{d}$ is the change in stock market prices in day $d$ of quarter $t$. Figure 5 plots realized variance of 12-month crude oil futures prices (solid line) and stock market prices (dashed line). Interestingly, oil price volatility is at least as high as stock market volatility, but the timing of the spikes generally do not coincide. The correlation coefficient between the two volatility measures is a modest 7 percent.

\section{WHAT EXPLAINS OIL PRICE VOLATILITY?}

Unanticipated economic developments could, in principle, roil crude oil markets and increase volatility. Recent examples include the unexpected surge in energy demand from China and India, which helped to draw down worldwide buffer stocks, and the decline in the tradeweighted value of the U.S. dollar. According to the International Monetary Fund's April 2004 World Economic Outlook,

This decline in commercial stocks and concerns about low U.S. gasoline inventories resulted in a noticeable increase in the volatility of oil prices and the average price of crude oil. A build up of large long speculative positions in futures markets also contributed to the increase in spot prices. (pp. 54-55)

Another cause of increased uncertainty could reflect exogenous events that are noneconomic in nature. ${ }^{7}$ Hamilton (1985) shows that several of the principal causes of increases in crude oil prices from 1947 to 1981 were labor strikes, political disturbances such as the Iranian revolution or the Suez Canal crisis, and wars. In practice, there are two methods that can be used to test whether economic developments or noneconomic developments are the principle cause of increased oil price volatility. Table 1 reports the first method,

\footnotetext{
7 These exogenous events, of course, could precipitate an economic policy response that might increase uncertainty in the oil markets: (i) a more restrictive response by the Federal Reserve in 1979 to combat rising inflationary pressures and heightened inflation expectations in the aftermath of the 1979 Iranian revolution and (ii) the Fed's more accommodative monetary policy in the immediate aftermath of the 2001 terrorist attacks in the United States.
}

a narrative approach that relates Wall Street Journal news accounts with the 10 largest daily price movements of the 12-month futures contracts over the period April 1983-December 2004. ${ }^{8}$ Most of the events associated with the largest percentage changes are related to developments among the Organization of the Petroleum Exporting Countries (OPEC) or political instabilities in the Middle East. Interestingly, among the 10 largest price changes, half occurred during 1986, when crude oil prices plunged. We also found similar results using the next 40 largest price movements (which are available upon request). We confirmed Hamilton's results using higherfrequency data.

The second method relies on formal statistical tests. Table 2 measures whether standard macrovariables forecast one-quarter-ahead realized oil futures variance. The predictive variables include past realized oil variance, $R V \_O$; the oil price change, $R E T \_O$; realized stock market variance, $R V \_S$; stock market return, $R E T \_S$; the default premium, DEF; the term premium, TERM; and the growth rate of real GDP, $D \_G D P$. The default premium is the difference between the yield on Baa- and Aaa-rated corporate bonds, and the term premium is the difference between the yield on 10-year Treasury notes and 3-month Treasury bills. A sizable literature suggests that yield spreads like these contain valuable information about current and prospective business conditions (e.g., see Dueker, 1997, and the references therein).

In Table 2 (row 1 of Panel A), realized oil price variance is strongly autocorrelated; the size of the coefficient is 0.565 . This result is consistent with those obtained from the other financial markets, such as the stock market, where volatility tends to persist at a high level after it rises (e.g., see Guo, 2002, and references therein). Interestingly, real GDP growth ( $\left.D \_G D P\right)$ is negativelyand significantly-related to realized oil price variance. However, as shown in Panel B of Table 2, it loses its predictive power after we add the lagged dependent variable to the regression. The other macrovariables, however, are not related to oil

8 We find similar results using futures contracts of different maturities. 


\section{Table 1}

\section{The Ten Largest Changes in 12-Month Crude Oil Futures Prices}

\begin{tabular}{|c|c|c|c|}
\hline & Date & Price change & Wall Street Journal Description \\
\hline 1 & 1/17/91 & -0.13 & $\begin{array}{l}\text { U.S. attacks Iraq. NYMEX opens with price controls on crude oil (first move of } \\
\$ 7.50 \text { halts trading for } 1 \mathrm{hr} \text {, the second in the same direction locks in a price } \\
\text { floor or ceiling). Feb. contract falls } \$ 10.56 \text {. Spot rose by } \$ 5 \text { then dropped } \$ 15 \text {. }\end{array}$ \\
\hline 2 & $8 / 5 / 86$ & 0.11 & $\begin{array}{l}\text { Oil prices soar on OPEC pact to cut output. Jump to } \$ 15 \text {-a-barrel mark was } \\
\text { prompted by news of two-month accord. }\end{array}$ \\
\hline 3 & $4 / 8 / 86$ & -0.098 & $\begin{array}{l}\text { White House appears likely to endorse repeal of "windfall profits" tax on crude } \\
\text { oil and moved to quell oil market jitters that U.S. support for free-market oil } \\
\text { prices could change if prices drop too much. Chevron chairman criticizes } \\
\text { Bush's remarks to Saudis. World oil prices plummeted on news that the Soviet } \\
\text { Union has begun selling oil in Europe through netback transactions that could } \\
\text { be adding more than a million barrels a day to overburdened world supply. }\end{array}$ \\
\hline 4 & 2/24/86 & 0.095 & $\begin{array}{l}\text { A Bermuda-based trading firm accused four major oil companies of conspiring } \\
\text { to force crude oil prices lower to maximize refining profits and minimize tax } \\
\text { payments. Saudi Arabia launched a campaign to deny responsibility for the } \\
\text { oil price collapse while continuing to expand its world oil market share in } \\
\text { ways certain to keep downward pressure on prices. }\end{array}$ \\
\hline 5 & 09/24/01 & -0.088 & $\begin{array}{l}\text { The Organization of Petroleum Exporting Countries plans to leave output quotas } \\
\text { unchanged because of uncertainty over the global economy. Crude-oil prices } \\
\text { tumbled } 17 \% \text { since Sept. 10, futures hit a } 22 \text {-month low. }\end{array}$ \\
\hline 6 & $10 / 22 / 90$ & -0.084 & $\begin{array}{l}\text { Crude oil futures for November delivery, which expired at yesterday's close, } \\
\text { skidded } \$ 5.41 \text { a barrel to } \$ 28.38 \text {. December futures were down the } \$ 3 \text { a barrel } \\
\text { daily limit. Crude oil falls below } \$ 30 \text { as sentiment shifts after statements in } \\
\text { Middle East. }\end{array}$ \\
\hline 7 & $10 / 25 / 90$ & 0.082 & $\begin{array}{l}\text { Oil prices surge again on new Middle East fears. Traders in the slippery oil } \\
\text { market bet that recent slide won't last. }\end{array}$ \\
\hline 8 & $8 / 4 / 86$ & 0.082 & OPEC considers oil-production quotas as Saudis' voluntary-cut plan stalls. \\
\hline 9 & $2 / 4 / 86$ & -0.082 & Oil contracts plunge as doubt grows. OPEC can stabilize petroleum prices. \\
\hline 10 & $8 / 27 / 90$ & -0.078 & $\begin{array}{l}\text { OPEC meets as oil picture deteriorates; some to seek "blessing" to raise their } \\
\text { output. A sense that Middle East tensions are easing. }\end{array}$ \\
\hline
\end{tabular}

NOTE: This table reports the ten largest daily price movements (percent) in 12-month crude oil futures and the associated Wall Street Journal reports. 


\section{Table 2}

\section{Forecasting One-Quarter-Ahead Realized Oil Price Variance}

\begin{tabular}{|c|c|c|c|c|c|c|c|c|}
\hline & $\boldsymbol{R} V_{-} O$ & RET_O & $R V \_S$ & RET_S & DEF & TERM & D_GDP & ARSQ \\
\hline \multicolumn{9}{|c|}{ A. Without controlling for the lagged dependent variable } \\
\hline 1 & $\begin{array}{l}0.565^{* * *} \\
(0.050)\end{array}$ & & & & & & & 0.310 \\
\hline 2 & & $\begin{array}{c}-0.001 \\
(0.069)\end{array}$ & & & & & & -0.012 \\
\hline 3 & & & $\begin{array}{c}0.154 \\
(0.251)\end{array}$ & & & & & -0.009 \\
\hline 4 & & & & $\begin{array}{l}-0.030 \\
(0.121)\end{array}$ & & & & -0.011 \\
\hline 5 & & & & & $\begin{array}{c}0.059 \\
(0.042)\end{array}$ & & & 0.055 \\
\hline 6 & & & & & & $\begin{array}{c}-0.008 \\
(0.005)\end{array}$ & & 0.004 \\
\hline 7 & & & & & & & $\begin{array}{c}-2.946^{* *} \\
(1.397)\end{array}$ & 0.044 \\
\hline
\end{tabular}

\section{B. Controlling for the lagged dependent variable}

\begin{tabular}{|c|c|c|c|c|c|c|c|c|}
\hline 8 & $\begin{array}{l}0.614^{* * *} \\
(0.057)\end{array}$ & $\begin{array}{c}0.062 \\
(0.047)\end{array}$ & & & & & & 0.330 \\
\hline 9 & $\begin{array}{l}0.565^{* * *} \\
(0.048)\end{array}$ & & $\begin{array}{c}0.029 \\
(0.153)\end{array}$ & & & & & 0.302 \\
\hline 10 & $\begin{array}{l}0.567^{* * *} \\
(0.049)\end{array}$ & & & $\begin{array}{l}-0.042 \\
(0.104)\end{array}$ & & & & 0.305 \\
\hline 11 & $\begin{array}{l}0.539 * * * \\
(0.071)\end{array}$ & & & & $\begin{array}{c}0.019 \\
(0.029)\end{array}$ & & & 0.308 \\
\hline 12 & $\begin{array}{l}0.560^{* * *} \\
(0.047)\end{array}$ & & & & & $\begin{array}{c}-0.002 \\
(0.004)\end{array}$ & & 0.303 \\
\hline 13 & $\begin{array}{l}0.541^{* * *} \\
(0.043)\end{array}$ & & & & & & $\begin{array}{r}-1.066 \\
(0.863)\end{array}$ & 0.309 \\
\hline 14 & $\begin{array}{l}0.537^{* * *} \\
(0.063)\end{array}$ & $\begin{array}{c}0.058 \\
(0.043)\end{array}$ & $\begin{array}{c}-0.136 \\
(0.213)\end{array}$ & $\begin{array}{l}-0.023 \\
(0.106)\end{array}$ & $\begin{array}{c}0.029 \\
(0.033)\end{array}$ & $\begin{array}{c}-0.004 \\
(0.005)\end{array}$ & $\begin{array}{c}-1.064 \\
(0.871)\end{array}$ & 0.304 \\
\hline
\end{tabular}

NOTE: The table reports the results of the forecasting regression for realized oil price variance over the period 1984:Q2-2004:Q4. Newey-West standard errors are reported in parentheses. ${ }^{* * *},{ }^{* *}$, and ${ }^{*}$ denote significance at the 1,5 , and 10 percent levels, respectively. ARSQ: Adjusted R ${ }^{2}$.

The independent variables are $R V_{-} O$, past realized oil variance; $R E T \_O$, the oil price change; $R V_{-} S$, realized stock market variance; $R E T \_S$, stock market return; $D E F$, the default premium; TERM, the term premium; $D \_G D P$, the growth rate of real GDP. 


\section{Table 3}

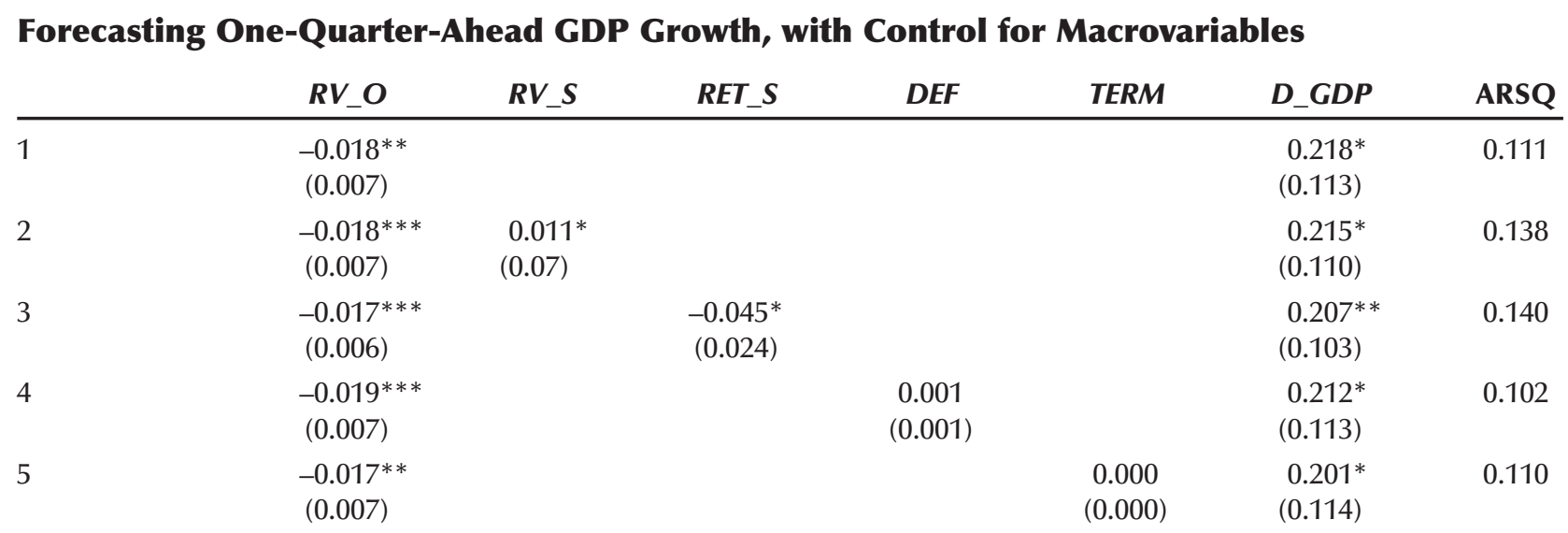

NOTE: See the note for Table 2.

price volatility in either panel. ${ }^{9}$ Therefore, our results are consistent with the evidence in Table 1 that oil price volatility originates mainly from exogenous shocks to the U.S. economy rather than endogenous responses to these shocks.

\section{OIL PRICE VOLATILITY AND GDP GROWTH}

As the previous discussion makes clear, increases in the relative price of crude oil tend to have negative effects on output and employment, because the increases act as a tax on consumption. Moreover, because firms also face higher costs, increases in oil prices also tend to increase inflation. ${ }^{10}$ In this section we test whether oil price volatility also has negative effects on output and, in particular, whether uncertainty causes a delay in business investment, as mentioned previously. We addressed this issue by investigating whether realized oil price variance $\left(R_{-} V O\right)$ forecasts onequarter-ahead real GDP growth; our results are reported in Table 3.

9 The growth of fixed nonresidential business investment also forecasts oil price volatility but loses the predictive power after we control for the lagged dependent variable. Moreover, changes in the federal funds rate target, a measure of monetary policy, have negligible forecasting power for realized oil price variance. These results are available upon request.

${ }^{10}$ See recent speeches by Greenspan (2004) and Bernanke (2004).
Row 1 of Table 3 shows that oil price variance does have a significantly negative effect, even after we controlled for past GDP growth. Stock and Watson (2003), among many others, show that many macroeconomic variables help forecast real GDP growth. To address this issue, we investigated the possibility that realized oil price variance forecasts real GDP growth merely because of its co-movement with the macroeconomic variables used in Table 2. We found that, although stock market returns (row 3 ) and volatility (row 2) are marginally significant, they do not significantly diminish the usefulness of realized oil price variance to forecast real GDP growth. Similarly, the default premium (row 4) and the term spread (row 5) do not reduce the significance of realized oil price variance to help forecast one-quarterahead real GDP growth.

\section{GRANGER CAUSALITY TESTS}

To formally address whether oil price uncertainty has a significant effect on output, we also conducted Granger causality tests (as in Hamilton, 1983, 1996, and 2003) and report the results in Table 4. In particular, we regressed real GDP growth on its own lags and lagged realized oil price variances as well as the other variables. If realized oil price variance has no effect on output, 
Table 4

Granger Causality Tests Using Realized Oil Price Variance

\begin{tabular}{|c|c|c|c|c|c|}
\hline Lags & $\boldsymbol{R} V \_O$ & RET_O & MAX_RET_O & D_GDP & ARSQ \\
\hline \multicolumn{6}{|c|}{ A. Quarterly data without oil prices } \\
\hline 1 & $\begin{array}{c}-0.020^{* *} \\
(0.009)\end{array}$ & & & $\begin{array}{c}0.133 \\
(0.106)\end{array}$ & 0.167 \\
\hline 2 & $\begin{array}{c}0.012 \\
(0.010)\end{array}$ & & & $\begin{array}{l}0.302^{* * *} \\
(0.089)\end{array}$ & \\
\hline$\chi^{2}(2)$ & $\begin{array}{c}5.579 \\
{[0.061]}\end{array}$ & & & $\begin{array}{l}18.063 \\
{[0.000]}\end{array}$ & \\
\hline
\end{tabular}

\section{B. Quarterly data with RET_O}

$\begin{array}{lccc}1 & -0.023^{* * *} & -0.004 & 0.127 \\ 2 & (0.009) & (0.003) & (0.100) \\ & 0.013 & 0.001 & 0.319 * * * \\ \chi^{2}(2) & (0.009) & (0.002) & (0.091) \\ & 9.249 & 2.229 & 18.437 \\ & {[0.010]} & {[0.328]} & {[0.000]}\end{array}$

\section{Quarterly data with $M A X \_R E T \_O$ oil prices}

$\begin{array}{lcccc} & -0.011 & -0.002 & -0.012 & 0.081 \\ 2 & (0.007) & (0.003) & (0.011) & (0.091) \\ & 0.010 & 0.003 & -0.027^{* * *} & 0.292^{* * *} \\ \chi^{2}(2) & (0.007) & (0.003) & (0.009) & (0.078) \\ & 3.276 & 2.785 & 10.485 & 16.203 \\ & {[0.194]} & {[0.248]} & {[0.005]} & {[0.000]}\end{array}$

\section{Monthly data with industrial production}

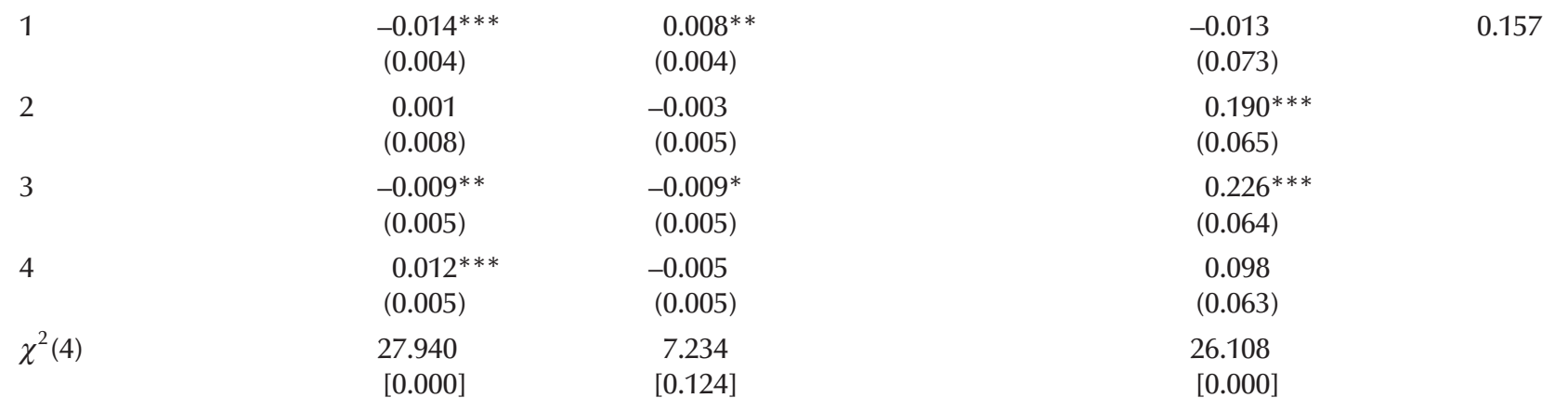

NOTE: The table reports the results of the forecasting regression for growth of real GDP (Panels A to C) and industrial production (Panel D) using realized oil price variance over the period 1984 to 2004. Newey-West standard errors are in parentheses; ${ }^{* *},{ }^{* *}$, and $*$ denote significance at the 1, 5, and 10 percent levels, respectively. The number of lags is determined by the Akaike information criterion. The last row of each panel reports the Wald test statistics (with the null hypothesis that lags of each variable are jointly insignificant), which has a $\chi^{2}$ distribution with the degrees of freedom equal to the number of lags; $p$-values for these Wald statistics are in brackets; ARSQ is adjusted $\mathrm{R}^{2}$; see variable descriptions in the note for Table 2. 
we should expect that its lags jointly have no explanatory power for real GDP growth. We tested this hypothesis using the Wald test, which has a $\chi^{2}$ distribution with the degrees of freedom equal to the number of lags. Unless otherwise indicated, we chose the number of lags (which is two in our sample) using the Akaike information criterion (AIC); however, we found qualitatively the same results using four lags, as in Hamilton (1983, 1996, and 2003).

In Panel A of Table 4, we included two lags of the realized oil price variance and the lagged dependent variable in the forecasting equation. Consistent with the results reported in Table 3, the one-quarter-lagged realized oil price variance is significantly negative; however, the two-quarterlagged realized variance is actually positive, although statistically insignificant. Overall, the Wald test indicates that realized oil price variance has a marginally significant effect, with a p-value of 6 percent.

We also included raw oil price changes $\left(R E T_{-} O\right)$ in the forecasting equation and report the results in Panel B of Table 4. In this specification, we explicitly considered two distinct effects of oil price changes on output and expect that both $R V \_O$ and $R E T \_O$ have negative effects. Interestingly, the Wald test indicates that the overall effect of realized oil price variance becomes significant at the 1 percent level. The sum of coefficients of lagged $R E T \_O$ is also negative, as expected; however, it is not statistically significant. Our results indicate that both channels might be important, because we uncovered more significant results when including both the oil price and its variance in the forecasting equation. As we show below, the coefficients on RET_O are not by themselves statistically significant, possibly because of the relatively small number of observations.

In Panel C of Table 4, we also include Hamilton's (2003) transformed oil price measure, $M A X \_R E T \_O$, with a 12-quarter horizon. It is negative and significant at the 1 percent level; moreover, it subsumes the information content of both the oil price change (RET_O) and its volatility $\left(R V_{-} O\right)$. This result provides support that Hamilton's specification captures overall effects of oil prices on aggregate output and, therefore, its forecasting abilities cannot be entirely attributed to data mining.

To check for robustness, we also analyzed monthly data for industrial production growth and report the results in Panel D of Table 4. Consistent with quarterly data, realized oil price variance is highly significant but the oil price change is not. ${ }^{11}$

With only 20 years of observations, we were concerned that the results might be sample specific. To address this issue, we also used a longer sample, originally analyzed by Hamilton (2003), and updated the data through 2004. We used the squared oil price change as a proxy for oil price volatility and report the results in Table 5 . Oil price variance by itself is not significant $\left(\chi^{2}\right.$ test statistic in Panel A) at the 10 percent level; however, it becomes marginally significant when combined with the change in oil prices, $R E T \_O$, which itself is highly significant (Panel B). Therefore, over the longer sample, we found that both channels through which oil prices affect the macroeconomy are important. Again, as shown in Panel C, both variables lose their forecasting power after we control for $M A X \_R E T \_O$, which itself is highly significant.

\section{OIL PRICE VOLATILITY, INVESTMENT, AND EMPLOYMENT}

As discussed previously, the delay hypothesis suggests that oil price volatility can affect output mainly because it deters business investment in capital goods, especially those with longer-service lives. ${ }^{12}$ Moreover, since employment growth tends to be highly dependent on output growth, a corollary to this hypothesis is that increases in oil price volatility decrease employment growth and increase the unemployment rate. Our results in Table 6 are generally consistent with this hypothesis.

\footnotetext{
${ }^{11}$ This finding is consistent with the results by Federer (1996), who found that oil price volatility improves forecasts of industrial production at a monthly frequency.

${ }^{12}$ More formally, if an investment is irreversible, increased uncertainty raises the option value of waiting to invest. See Bernanke (1983), Pindyck (1991), and Hubbard (1998).
} 
Table 5

Granger Causality Tests: 1947:Q2 to 2004:Q4

\begin{tabular}{|c|c|c|c|c|c|}
\hline Lags & $R V_{-} O$ & RET_O & MAX_RET_O & D_GDP & ARSQ \\
\hline \multicolumn{6}{|c|}{ A. Without oil prices } \\
\hline 1 & $\begin{array}{c}-0.020^{* *} \\
(0.010)\end{array}$ & & & $\begin{array}{l}0.285^{* * *} \\
(0.062)\end{array}$ & 0.123 \\
\hline 2 & $\begin{array}{c}-0.006 \\
(0.101)\end{array}$ & & & $\begin{array}{c}0.133^{*} \\
(0.078)\end{array}$ & \\
\hline 3 & $\begin{array}{c}-0.008 \\
(0.107)\end{array}$ & & & $\begin{array}{c}-0.086 \\
(0.064)\end{array}$ & \\
\hline 4 & $\begin{array}{c}-0.014 \\
(0.008)\end{array}$ & & & $\begin{array}{c}-0.121 \\
(0.074)\end{array}$ & \\
\hline$\chi^{2}(4)$ & $\begin{array}{c}6.410 \\
{[0.171]}\end{array}$ & & & $\begin{array}{c}34.449 \\
{[0.000]}\end{array}$ & \\
\hline
\end{tabular}

\section{B. With RET_O}

$\begin{array}{lccc}1 & -0.024^{* * *} & -0.002 & 0.271^{* * *} \\ 2 & (0.009) & (0.005) & (0.061) \\ & -0.002 & -0.007 & 0.126 \\ 3 & (0.007) & (0.004) & (0.077) \\ & -0.011 & -0.002 & -0.083 \\ 4 & (0.009) & (0.004) & (0.062) \\ & -0.010 & -0.016^{* * *} & -0.129^{*} \\ \chi^{2}(4) & (0.014) & (0.004) & (0.071) \\ & 8.742 & 17.491 & 33.122 \\ & {[0.068]} & {[0.002]} & {[0.000]}\end{array}$

\section{With RET_O and MAX_RET_O}

$\begin{array}{lcccc}1 & -0.013 & 0.000 & -0.018 & 0.224^{* * *} \\ 2 & (0.009) & (0.004) & (0.019) & (0.062) \\ & 0.006 & -0.001 & -0.019 & 0.110 \\ 3 & (0.010) & (0.005) & (0.019) & (0.075) \\ & -0.007 & 0.004 & -0.017 & -0.097 \\ 4 & (0.011) & (0.005) & (0.013) & (0.060) \\ & 0.008 & -0.002 & -0.042^{* * *} & -0.157^{* *} \\ \chi^{2}(4) & (0.014) & (0.004) & (0.013) & (0.070) \\ & 3.034 & 1.116 & 28.237 & 24.588 \\ & {[0.552]} & {[0.892]} & {[0.000]} & {[0.000]}\end{array}$

NOTE: The table reports the results of the forecasting regression for GDP growth using realized oil price variance over the period 1984-2004. Newey-West standard errors are in parentheses. ${ }^{* *},{ }^{* *}$, and ${ }^{*}$ denote significance at the 1, 5, and 10 percent levels, respectively. The last row of each panel reports the Wald test statistics, which determine whether the lags of each variable are jointly insignificant. These statistics have a $\chi^{2}$ distribution with the degrees of freedom equal to the number of lags; $p$-values for these Wald statistics are in brackets. See variable descriptions in the note for Table 2. 


\section{Table 6}

\section{Forecasting GDP Components and Labor Market Variables}

\begin{tabular}{|c|c|c|c|c|}
\hline Lags & $R V_{-} O$ & RET_O & $\begin{array}{c}\text { Lagged } \\
\text { dependent variable }\end{array}$ & ARSQ \\
\hline \multicolumn{5}{|c|}{ A. Nonresidential business fixed investment } \\
\hline 1 & $-0.072 * * *(0.025)$ & $0.003(0.008)$ & $0.254^{* *}(0.100)$ & \multirow[t]{3}{*}{0.329} \\
\hline 2 & $0.010(0.029)$ & $0.006(0.008)$ & $0.305^{* * *}(0.109)$ & \\
\hline$\chi^{2}(2)$ & $10.378[0.006]$ & $0.593[0.743]$ & $17.749[0.000]$ & \\
\hline \multicolumn{5}{|c|}{ B. Structures investment } \\
\hline 1 & $-0.157^{* * *}(0.050)$ & $0.028 *(0.017)$ & $0.044(0.099)$ & \multirow[t]{3}{*}{0.215} \\
\hline 2 & $0.041(0.054)$ & $0.018(0.015)$ & $0.262 * *(0.108)$ & \\
\hline$\chi^{2}(2)$ & $13.855[0.000]$ & $6.737[0.034]$ & $5.949[0.051]$ & \\
\hline \multicolumn{5}{|c|}{ C. Equipment and software investment } \\
\hline 1 & $-0.034(0.049)$ & $-0.008(0.008)$ & $0.239 * *(0.104)$ & \multirow[t]{3}{*}{0.173} \\
\hline 2 & $-0.036(0.029)$ & $-0.000(0.013)$ & $0.232 * *(0.104)$ & \\
\hline$\chi^{2}(2)$ & $6.565[0.038]$ & $0.918[0.632]$ & $10.999[0.004]$ & \\
\hline
\end{tabular}

D. Personal consumption expenditures, durable goods

$\begin{array}{lrcc}1 & -0.035(0.053) & -0.017(0.015) & -0.284^{* * *}(0.108) \\ 2 & -0.036(0.062) & -0.027(0.020) & -0.166(0.166) \\ \chi^{2}(2) & 0.847[0.655] & 2.638[0.267] & 6.914[0.032]\end{array}$

\section{E. Personal consumption expenditures, nondurable goods}

$\begin{array}{lrccc}1 & -0.012(0.016) & -0.008 *(0.004) & -0.079(0.112) & 0.016 \\ 2 & -0.005(0.012) & 0.003(0.003) & 0.157(0.118) & 3.312[0.191]\end{array}$

\section{F. Personal consumption expenditures, services}

$\begin{array}{lccc}1 & -0.021^{* * *}(0.007) & -0.005^{* *}(0.002) & 0.229^{* *}(0.101) \\ 2 & 0.017^{* * *}(0.005) & -0.000(0.002) & 0.254^{* * *}(0.097) \\ \chi^{2}(2) & 13.577[0.001] & 6.340[0.042] & 26.584[0.000]\end{array}$

\section{G. Nonfarm payroll employment}

\begin{tabular}{|c|c|c|c|c|}
\hline $\begin{array}{l}1 \\
2 \\
\chi^{2}(2)\end{array}$ & $\begin{array}{c}-0.003 * * *(0.001) \\
0.003 * *(0.001) \\
19.193[0.001]\end{array}$ & $\begin{array}{c}-0.000(0.000) \\
-0.001 * *(0.000) \\
6.862[0.032]\end{array}$ & $\begin{array}{c}0.813 * * *(0.123) \\
0.042(0.111) \\
338.159[0.000]\end{array}$ & 0.748 \\
\hline \multicolumn{5}{|c|}{ H. Civilian unemployment rate } \\
\hline $\begin{array}{l}1 \\
2 \\
\chi^{2}(2)\end{array}$ & $\begin{array}{l}0.795^{* * *}(0.189) \\
-0.744 * * *(0.267) \\
20.150[0.000]\end{array}$ & $\begin{array}{r}0.147(0.096) \\
-0.116(0.081) \\
3.897[0.142]\end{array}$ & $\begin{array}{c}1.507^{* * *}(0.089) \\
-0.537^{* * *}(0.089) \\
2,693.344[0.000]\end{array}$ & 0.973 \\
\hline
\end{tabular}

NOTE: The table reports the results of the one-quarter-ahead forecasting regression for GDP components, payroll employment, and the unemployment rate, using realized oil price variance over the period 1984-2004. Newey-West standard errors are reported in parentheses. ${ }^{* * *}, * *$, and ${ }^{*}$ denote significance at the 1,5 , and 10 percent levels, respectively. The last row of each panel reports the Wald test statistics, which determine whether the lags of each variable are jointly insignificant. These statistics have a $\chi^{2}$ distribution with the degrees of freedom equal to the number of lags; $p$-values for these Wald statistics are in brackets. The independent variables are $R V \_O$, past realized oil variance, and $R E T \_O$, the oil price change. 


\section{Guo and Kliesen}

As seen by the Wald statistics in Panel A of Table 6, forecasts for real business (nonresidential) fixed investment (BFI) growth one quarter ahead improve with the use of the volatility $\left(R V_{-} O\right)$ but not the level of oil prices (RET_O). ${ }^{13}$ Moreover, the sum of the coefficients of the lagged values of $R V \_O$ are negative, meaning that increases in oil price volatility predict weaker growth of BFI in the following quarter. We reestimated the regression using the two components of BFI: structures (Panel B) and equipment and software (Panel C). In the former case, lagged oil prices and lagged oil price volatility are statistically significant predictors, but in the latter case, only volatility matters (the signs were also correct).

In the next three panels, we report results for forecasts of consumption of real durable goods (Panel D), real nondurable goods (Panel E), and real services (Panel F). Both the level and volatility of oil prices appear to have little effect on the growth of consumption of durable goods and nondurable goods, which may be surprising to some because the conventional wisdom is that higher oil prices act as a consumption tax. However, they are both significant in the forecast of real services, perhaps because they include expenditures on such items as utilities and transportation services, which are energy sensitive.

The final two panels report results for onequarter-ahead forecasts of nonfarm employment (Panel G) and the unemployment rate (Panel H). Both the level and volatility of oil prices are significant in forecasting employment, whereas only volatility matters for forecasting the unemployment rate.

\section{CONCLUSION}

The results of this paper are consistent with much of the previous research that suggests that oil matters. In particular, using a measure of volatility constructed from daily crude oil futures prices traded on the NYMEX, we find that over the period 1984-2004 oil price volatility has had a significant and adverse effect on various key

${ }^{13}$ Because of the relatively small sample size, in Table 6 we set the number of lags to 2 . measures of the U.S. macroeconomy such as fixed investment, consumption, employment, and the unemployment rate. This finding, which is consistent with the nonlinear effect documented by Hamilton (1996 and 2003), means that an increase in the price of crude oil from, say, $\$ 40$ to $\$ 50$ per barrel generally matters less than increased uncertainty about the future direction of prices (increased volatility).

We also find that standard macroeconomic variables do not forecast realized oil price volatility, which suggests that changes in the supply and demand for crude oil that raise the variance of future crude oil prices tend to reflect stochastic disturbances. This finding implies that crude oil price volatility is mainly driven by exogenous (random) events such as significant terrorist attacks and military conflicts in the Middle East.

\section{REFERENCES}

Andersen, Torben G.; Bollerslev, Tim, Diebold, Francis X. and Labys, Paul. "Modeling and Forecasting Realized Volatility." Econometrica, March 2003, 71(2), pp. 579-625.

Baily, Martin Neal. "Productivity and the Service of Capital and Labor." Brookings Papers on Economic Activity, 1981, 1, pp. 1-50.

Barsky, Robert B. and Kilian, Lutz. "Oil and the Macroeconomy Since the 1970s." Journal of Economic Perspectives, Fall 2004, 18(4), pp. 115-34.

Bernanke, Ben S. "Irreversibility, Uncertainty, and Cyclical Investment.” Quarterly Journal of Economics, February 1983, 98(1), pp. 85-106.

Bernanke, Ben S. "Oil and the Macroeconomy." Remarks at the Distinguished Lecture Series, Darton College, Albany, Georgia, October 21, 2004.

Dueker, Michael D. "Strengthening the Case for the Yield Curve as a Predictor of U.S. Recessions." Federal Reserve Bank of St. Louis Review, March/April 1997, 79(2), pp. 41-51.

Federer, J. Peter. "Oil Price Volatility and the Macroeconomy." Journal of Macroeconomics, Winter 1996, 18(1), pp. 1-26. 
Greenspan, Alan. “Oil.” Remarks to the National Italian American Foundation, Washington, DC, October 15, 2004.

Guo, Hui. "Stock Market Returns, Volatility, and Future Output.” Federal Reserve Bank of St. Louis Review, September/October 2002, pp. 75-85.

Hamilton, James D. "Oil and the Macroeconomy since World War II." Journal of Political Economy, January 1983, 91(2), pp. 228-48.

Hamilton, James D. "Historical Causes of Postwar Oil Shocks and Recessions.” The Energy Journal, January 1985, 6(1), pp. 97-116.

Hamilton, James D. "This Is What Happened to the Oil Price-Macroeconomy Relationship.” Journal of Monetary Economics, October 1996, 38(2), pp. 215-20.

Hamilton, James D. “A Neoclassical Model of Unemployment and the Business Cycle." Journal of Political Economy, 1988, 96(3), pp. 593-617.

Hamilton, James D. "What Is an Oil Shock?" Journal of Econometrics, 2003, 113(2), pp. 363-98.

Hooker, Mark A. "What Happened to the Oil PriceMacroeconomy Relationship?" Journal of Monetary Economics, 1996a, 38(2), pp. 195-213.

Hooker, Mark A. "This is What Happened to the Oil Price-Macroeconomy Relationship: Reply." Journal of Monetary Economics, 1996b, 38(2), pp. 221-22.

Hubbard, R. Glenn. "Capital-Market Imperfections and Investment." Journal of Economic Literature, March 1998, 36(1), pp. 193-225.
International Monetary Fund. "Economic Prospects and Policy Issues." World Economic Outlook: Advancing Structural Reforms, April 2004, pp. 22-62.

Jones, Donald W.; Leiby, Paul N. and Paik, Inja K. "Oil Price Shocks and the Macroeconomy: What Has Been Learned Since 1996?” The Energy Journal, 2004, 25(2), pp. 1-32.

Lilien, David M. "Sectoral Shifts and Cyclical Unemployment." Journal of Political Economy, August 1982, 90(4), pp. 777-93.

Merton, R. "On Estimating the Expected Return on the Market: An Exploratory Investigation.” Journal of Financial Economics, December 1980, 8(4), pp. 323-61.

Pindyck, Robert. "Irreversibility, Uncertainty, and Investment.” Journal of Economic Literature, September 1991, 29(3), pp. 110-48.

Rasche, Robert H. and Tatom, John A. "The Effects of the New Energy Regime on Economic Capacity, Production, and Prices." Federal Reserve Bank of St. Louis Review, May 1977a, 59(5), pp. 2-12.

Rasche, Robert H. and Tatom, John A. "Energy Resources and Potential GDP." Federal Reserve Bank of St. Louis Review, June 1977b, pp. 10-24.

Stock, James H. and Watson, Mark W. "Forecasting Output and Inflation: The Role of Asset Prices.” Journal of Economic Literature, September 2003, 41(3), pp. 788-829.

Wei, Chao. "Energy, the Stock Market, and the PuttyClay Investment Model.” The American Economic Review, March 2003, 93(1), pp. 311-23. 
